\title{
"Boundary" in ancient Persian tradition of statehood: an introduction to the origins of the concept of boundary in pre-modern history
}

\author{
Pirouz Mojtahed-Zadeh
}

Published online: 19 September 2006

(C) Springer Science+Business Media B.V. 2006

\section{Erratum to: GeoJournal 62: 51-58 DOI 10.1007/s10708-005-8562-2}

The erroneous version of this article was originally published in GeoJournal 62: 51-58. This amended version corrects the formatting errors which are evident in the original version.

\begin{abstract}
It is universally accepted that the need for defining precise lines of separation and points of contacts between states is the byproduct of the emergence of nation-states and 'world economy' in the nineteenth century Europe. Nevertheless, it is hard to overlook the fact that these modern notions are rooted in periods prior to the emergence in Europe of nation-states. There are indications that ancient civilizations were familiar with the notion of 'state' in connection with the concepts of territory and boundary. Ancient texts reveal that this basic principle existed in ancient Persian literature in respect of matters of state, territory, and boundary. Similarly, the likelihood exists that these Persian notions could have influenced Roman civilization. It is widely
\end{abstract}

The online version of the original article can be found at http://dx.doi.org/10.1007/s10708-005-8562-2

P. Mojtahed-Zadeh $(\bowtie)$

T.M. University, Tehran, Iran

Urosevic Research Foundation, London, UK

e-mail: pirouzmojtahedzadeh@hotmail.com believed that a combination of ancient GrecoRoman and Persian civilizations is a major contributor to what culturally constitutes 'West'. Later in the Sassanid period the inter-linked notions of state, territory, and boundary developed substantially, coming quite close to their contemporary forms. On the other hand, considering that 'justice' was the corner stone of ancient Persian Political philosophy, the idea that ancient Iranian spatial arrangement might have contributed to the evolution of the concept of democracy in the West may not be too difficult to contemplate.

Keywords Achaemenids · Boundary ·

Democracy $\cdot$ Justice $\cdot$ Persia $\cdot$ State $\cdot$ The West

\section{Introduction}

While the concept of frontier as a vast area or a zone of contact (Kristof, 1959: 259-262) between two states is old and was well established before the modern era, many scholars treat the concept of boundary as if it were the product of the past few hundred years. Mirroring a tendency found in the political scientists literature, many political geographers treat the concept of 'state'-with its 'boundary' component-as a product of the peace treaty of Westphalia in 1648 (Glassner \& de Blij, 1989: 46-59). Moreover, it is also widely accepted 
that the need for a precise territorial definition and segregation of states was an inevitable concomitant of modernity. This new concept is treated as the necessary outcome of imperialism's global aspirations, with its inherent global economic order and trade and communication systems (Taylor, 1989: 144-146).

The concept of 'state' and 'boundary', however seems to be older than modern era as 'boundary' exists only in association with a 'state' system - the legitimacy of which being tied to the normative territorial ideas (which are old): states should be discrete territories and that the pattern of states should reflect the pattern of nations (Murphy, 2003). There is little doubt that the modern concepts of state and territory were developed in modern Europe; nevertheless it is hard to overlook the fact that they are rooted in the periods prior to the emergence in Europe of nation-states. There are indications that ancient civilizations were familiar with the notion of 'state' in connection with territorial and boundary characteristics similar to modern states. The Great Wall of China, the Hadrian Wall of Roman Britain, and Sadd-e Sekandar (Alexander's Wall) in northeast Iran $^{1}$ might indeed have been

\footnotetext{
${ }^{1}$ This wall was built at the time of the Parthian civilization in Iran (247 BC-224 AD) to separate that civilization from the Turans of the East

2 The term "Iran" has constituted as the official name of the country or state known by that name in the Middle East, at least since the emergence of the Achaemenid federative state in 6th century BC. The West came to know this country as "Persia" through the Greeks of the citystates which in the 6th century BC, was not as yet familiar with the concept of state-cum-country. They named Iran as "Persia" in accordance with the on-going tradition of naming places after the name of the dynasties or ethnic groups ruling them. Hence, they named Iran as "Persia" in reference to the province of Persia in southern Iran where the Achaemenid dynasty had emerged from in mid-6th century BC. This was in accordance with the Greek tradition of political geography of the time, whereas the Iranians of the Achaemenid era were familiar with the concept of state-cum-country and the need to name countries by a term that would not exclusively refer to a particular group or ethnicity among many, but a term common to all in a federative system. It is noteworthy that the term "Iran" means the land of the Aryans and it is a name in reference to all peoples of Iranic ethnic background; peoples like the Persians, the Kurds, the Baluchis, the Guilaks, the Mazandaranis, the Khuzistanis, the Khorasanis, and the Azeris, etc.
}

parts of wider peripheral zones of contact in ancient world (Taylor, 1989: 146). Yet, it is inevitable that even in that capacity they represented the notion of a 'line' in space designed to separate the proverbial 'us' from 'them'. In other words they embodied the basic principle for boundary separation. Indeed, there are references in ancient Persian literature to modernlike states, territories, and boundaries. Similarly when considering the scale of both belligerent and peaceful contacts between Roma and Iran (Persia) ${ }^{2}$, the likelihood exists that these Persian notions could have influenced Roman civilization.

A combination of ancient Greek/Roman and Persian civilizations however, is said to have been a major source of contribution to what culturally constitutes "West" in our time. Taking into consideration the extent to which Greek and Roman civilizations interacted with that of ancient Persia, little doubt remains about validity of Jean Gottmann's assertion in his letter to this writer (1987) that

Iran must have belonged to the 'Western' part of mankind, and I suspect that this was what Alexander the Great of Macedonia, a pupil of Aristotle, therefore, in the great Western philosophical tradition, found in Iran and that attracted him so much that he wanted to establish a harmonious, multinational cooperation between the Iranians and Greeks within the large empire he was building $^{3}$

Verification of this can be sought in historical events, as when conquering Iran Alexander the Great claimed in Persepolis that he was the 'true successor to the Achaemenid Darius III'. Ferdosi (1020 AD), the famous Persian epic

\footnotetext{
${ }^{3}$ Professor Jean Gottmann, whose student this author was at Oxford University in late 1970s, authorized this quotation from his said letter, in a separate note dated 19th May 1992.
} 
poet says of this in his Shahnameh (book of kings $)^{4}$ that: having conquered Iran, Alexander wrote to the nobles of the country apologizing for having done away with their king Dara (Darius III). Moreover, Alexander reassured them that: if Dara is no more, I am here and Iran will remain the same as it has always been since its beginning. $\mathrm{He}$ adopted the existing (Achaemenid) political organization of space, which was modified later by his successors. Alexander also proclaimed justice to be the goal, attainment of which will be his mission in Iran.
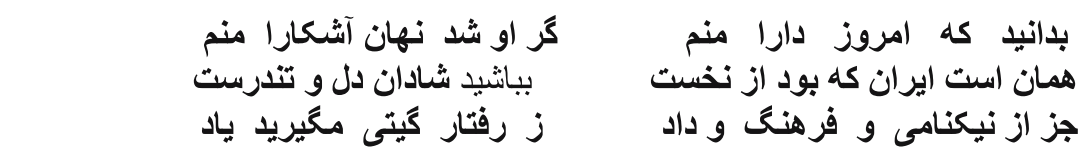

Bedanid ke emrooz Dare mamam

Garoo shod Naha
Haman ast Iran ke blood az, nakhost

Bebashid shadan del-o tenderst

Joz as niknami-o farhang-o daad

Literally meaning:

Ze rafter-e guiti magirid yad

\author{
Be informed that today I am Dara \\ If he has disappeared, I am to be seen \\ Iran is as it has been from the start \\ Do remain healthy and happy in heart \\ But of good name, culture and justice \\ Learn not from the ways of the world
}

(Ferdosi, 1985: III, 330).

\footnotetext{
4 Shahnameh (book of kings) of Abul-Qassem Ferdosi (d. $1020 \mathrm{AD}$ ) is widely praised as the only reliable source in Persian literatures that studies pre-Islamic history of Iran and its association with other political entities of the antiquity, but hitherto little attention has been paid to the way it describes political relations in association with political organization of the space in the ancient world. Popularly known as an epic account of ancient Persian history, especially of the Sassanid period (224-651 AD), theShahnameh provides a remarkable description of the development of the concept of state in ancient Iran. It carefully describes how the idea of a vertically organized state evolved in ancient Iran with clearly demarcated boundaries, which influenced such Western political conceptions as 'state', 'territory', 'boundary', and 'democracy'. Ferdosi's description of political geography of ancient world bears remarkable resemblance to the modern concepts of political geography that evolved in post-Westphalia Europe. But is it possible that he, who lived a thousand years ago, well before Westphalia treaty of 1648, had learnt these ideas from modern Europe or the fact is that what Ferdosi had described in terms of evolution of political thoughts and political geography in ancient Persia had influenced medieval Europe. This is certainly a fascinating question deserving further exploration with the help of reliable analysis of the sociopolitical developments of the ancient world
}

Later in the Sassanid period the inter-linked notions of state, territory, and boundary developed substantially, coming close to their contemporary forms. However to arrive at a better analysis of these ancient Persian notions, a brief introduction to the history of ancient Iran's political geography seems to be much consequence.

\section{State, territory, and boundary in ancient Persia}

Although the Achaemenids waged wars and captured territories, in their overall political conception of space, they were more culturally oriented than concerned with the rigidity of physical space. Various satrapies were defined along the lines of cultural and ethnic divides. Indeed, eminent scholars like Daurant (1988: 412, trans.) and Filippani-Ronconi (1978: 67) maintain that the concept of 'state' is an original Persian 
invention, which was later adopted by the West through the Romans. Quoting from Glover's writings on Persian civilization Nayer-Nouri, an eminent researcher of ancient Persian civilization, asserts that: the Persians set new ideas before mankind, ideas for the world's good government with utmost of unity and cohesion combined with the largest possible freedom for the development of race and individual within the larger organization (Nayer-Nouri, 1971: 196).

Ancient Greek historian/geographers like Herodotus (484?-425 BC) and Xenophon (430?355 BC) confirm that the Achaemenids (559-330 BC) founded a federal kind of state, a vast commonwealth of autonomous nations. Founder of this federation, Cyrus (Kurosh) the Great (559$529 \mathrm{BC}$ ) together with his successors substantially expanded their new commonwealth, and divided it into many satrapies (thirty to forty at times), each governed by a local Satrap, a Khashthrapavan or a vassal king. This was a commonwealth of global proportions, which included lands of Trans-Oxania, Sind, and Trans-Caucasus as far as what are now Moldavia, Trans-Jordan and Syria, Macedonia and Cyprus, Egypt and Libya. This was a political system of universal aspirations; ruled by a Shahanshah (king of kings). Thus it could also be referred to as the 'Shahanshahi' system. The king of kings in that system was not a lawgiver but the defender of laws and religions of all in the federation (Templeton, 1979: 14). Moreover in a state described by Glover (ibid) as good government that the Achaemenids created, and according to Cyrus's proclamation in Babylonia $^{5}$ that all were equal in his realm, ethnic or cultural groups enjoyed large measures of independence in the practice of their language, religion and economies. To uphold cultural and political independence of varying peoples of the federation and to respect their religions, the king of kings did not lay claim to any specific religion. Consequently the peoples of conquered territories were free to keep their religions, laws and traditions. Having conquered Babylonia for instance, Cyrus the Great found thousands of Jews in captivity there. His response was to free them

\footnotetext{
5 The text of this proclamation is in cuneiform Acadian (Akkadian), inscribed on a clay cylinder now in British Museum's Persian section
}

and send them back to their place of worship. $\mathrm{He}$ did not proceed to conquer Jerusalem, but his respect for captive Jews' religious freedom guaranteed their good will towards the Iranians. He became their prophet and they became the voluntary citizens of the Persian federation. Cyrus commissioned the building of their temple and their reaction was to assess his work as fulfilment of the prophecy of Isaiah (chapter xliv) where it says:

I am the lord...that saith of Cyrus, he is my shepherd, and shall perform my pleasure: even saying to Jerusalem, thou shalt be built: and to the temple, thy foundation shall be laid. (Lockhart, 1953: 326)

Many have tried hard to determine a 'dark side' to this early example of a 'federative state' and/or 'good government'. The best that some party political considerations of our time could have contemplated-such as the former Baath Party in Iraq-has been to equate Cyrus with a warmongering king who supported the Zionists (the Jews in captivity in Babylonia). They blame Cyrus for waging wars on varying nations, implying that the vast commonwealth of the Achaemenid state has come about by the force of the arm. These criticisms are based on blatant anachronisms. Babylonia was not an Arab state but an Akkadian civilization; the Arabs first appeared in Mesopotamia when the Sassanid state created the vassal kingdom of Hirah according to Arab historian/geographers like Masudi (1977) and Maqdasi (1906) who have also indicated that Arab settlement of southern Mesopotamia increased after the advent of Islam; and finally the captive Jews in Babylonia have nothing to do with Zionism which is a 20th century phenomenon. Moreover, war has always been an inherent part of political behaviour of mankind. Even in the age of modernity when "war" is detested as an act of immorality in the domain of human behaviour, there are the moralists who defend the so-called "Just war". Babylonia was an Akkadian civilization ruled by tyranny according to biblical texts; therefore Cyrus's war against Babylonian tyranny can easily qualify as a 'just war'.

On the other hand, our knowledge of ancient Iran and its role in the ancient world is largely 
shrouded in obscurity and our information, all too scanty as it is, derived from foreign sources (Iliff, 1953) who were at war with Iran most of the time. It is indeed a matter of regret that we do not have historical accounts from pre-Islamic Iranians themselves that would deal with details of wars and political conflicts that involved ancient Persia or analysing social structure and religious and gender status or differences of groups and individuals in ancient Persian societies. All we know is that the decree that Cyrus issued in Babylonia was about freedom and equality for all, including the Babylonians and the captive Jews alike, and it was for this broad-minded policy that he is so praised in the biblical literatures of the West and Islam. And that it was because of this broadminded policy of the Achaemenid king that won allegiance of many peoples including the Greeks of Ionian cities (Templeton, 1979), Cyprus and Jerusalem who joined their federation and that, other than the force of arm there must have been certain attractions in that system of government for them to join it voluntarily.

\section{'Justice' as the foundation-stone of Persian state system}

Considering that 'justice' was the corner stone of ancient Iranian political philosophy, the idea that ancient Iranian spatial arrangement have contributed to the evolution of the concept of democracy in the West cannot be too difficult to contemplate. There are those who claim that when Cyrus the Great founded the federative state of many nations in what was to become the Persian Empire ${ }^{6}$, did not invent tolerance, righteousness, and happiness for the people out of genius of his own, but that he was following a deep-rooted age-old tradition of how an ideal king should behave. He had inherited the tradition of good government based on justice,

\footnotetext{
${ }^{6}$ Some suggest that the concept of empire is perhaps a Roman adoption of the Persian Shahanshahi system (Tavakoli, 1993: 828-830). However, the difference between the two is that while various nations and ethnic groups lived autonomously in the Shahanshahi system of Iran, peoples of different national and ethnic backgrounds enjoyed no autonomy or self-rule in the imperial system that the Romans developed
}

toleration of others and respects for varying religious beliefs from the Medes whose king; Deicos (Diaxus) had collected all Iranians into one nation (Nayer-Nouri, 1971: 188). Nevertheless, the earliest available evidence suggesting that justice formed the foundation of the good government in ancient Persian tradition of statehood as the Achaemenid king decreed freedom and equality when conquering Babylonia in $539 \mathrm{BC}$.

This tradition was observed by all those succeeded Cyrus in Iran throughout its pre-Islamic history. According to the stales left behind at Naghsh-e Rostam in western Iran, Darius I (Dariush), known as Darius the Great (521-486 BC), organized thirty satrapies, each under an autonomous king assisted by a Satrap representing central authority of the king of kings. He appointed commanders of army and secretaries of political affairs. He fixed the tributes of each satrapy: appointed tribute-collectors and travelling inspectors called eyes and ears of the great king, to watch over the Satraps and army commanders. He introduced currencies of gold darics and silver siglus facilitating trade exchange in the federation (Nayer-Nouri, 1971: 221): built the 2,700 km long Royal Road from Susa, northwest of Persian Gulf, to Sardis on the Aegean Sea with branches to Persepolis and other political and commercial centres (Mojtahed-Zadeh, 1974: pp. $4-5,56-59)$. He ordered for the map of this road and civilized countries alongside it to be engraved on a plate of bronze, ${ }^{7}$ which was perhaps the first detailed geographic map in history. He established a postal service with relays of men and horses at short intervals, and caused a canal to be dug in Egypt to link Red Sea to the Nile (see Arbery, 1953).

In matters of state politics, while the Athenians were busy with their peculiar version of citizenship-oriented democracy, the Achaemenids, as

\footnotetext{
${ }^{7}$ A plate of bronze or other metals is called jam in Persian. Similarly a goblet of metal or crystal is jam. On the other hand, Shahnameh of Ferdosi speaks of legendary Jamshid Shah, founder of Iran, who had a jam showing the world. From this concept comes the mystical crystal ball in almost all cultures. Yet, this author is of opinion that Jamshid Shah was none other than Darius the Great who had the bronze disc jam showing the map of the civilized world. There are other reasons supporting this theory the discussion on which goes beyond the scope of this article
} 
has been elaborated, were forging a state system based on independence for cultural groups or nationalities; a federative system in which peoples of varying cultural backgrounds were given the right of governing their affairs autonomously with their religion and cultural identity respected. Thus it seems quite plausible that equality and justice were the essence of governing in that ancient tradition of statehood. The administration of justice however reached its zenith in the Sassanid period in the person of Anushirvan the Just, and it might be plausible to assume that these early Persian traditions of political philosophy have contributed to the development of modern concepts of democracy in the West. Some suggest (see Tavakoli, 1998) that the concept of empire is perhaps a Roman adoption of the Persian Shahanshahi system. On the same premise it may not be difficult to presume that the Romans evolved their idea of SENATE on the basis of ancient Parthian MEHESTAN, the House of the Elders, or the vice versa.

\section{Evolution of state and boundary under the Sassanids}

The Parthians (247 BC-224 AD) who succeeded the Macedonians in Persia created two kinds of autonomies in the federation: the internal satrapies and the peripheral dependent states-with 18 of the latter enjoying greater autonomy (Vadiei, 1974: 186). This system was revived by the Safavids in the 16th century Iran in the form of ialats and biglarbeigis.

Around the dawn of Christian era, the concepts of state and territory assumed greater sophistication with the advent of the notion of frontier or boundary in Iran. This was primarily the result of greater centralization of power vis-à-vis new threats from powerful adversaries such as the Roman Empire to the west and the Turans to the east. The political organization of space in the

\footnotetext{
${ }_{8}$ Turan is a term used by Ferdosi (d. AD 1020) in his Shahnameh, the greatest work of epic literature in Persian language, in reference to peoples of Turkic origin in the eastern fringes of Iran. What constitutes 'Central Asia' now was 'Greater Khorasan' in most parts of the postIslamic Iranian geography and its eastern most formed parts of "Turan" before that
}

Sassanid federation (224-651 AD) was marked by the development of such concepts as internal and external frontier-keeping states, buffer states, boundary pillars, etc. There are even hints in the ancient literature of river boundary between Iran and Turan in Central Asia. ${ }^{8}$

A look at the works of Persian literature relevant to Iran's ancient political geography such as Ferdosi's Shahnameh reveals that the Sassanids successfully developed the concepts of 'territory' within the framework of defined boundaries. They created an elaborated system of territorial organization of state. To begin with, the founder of the dynasty revived the Achaemenid political organization of the state, but divided it into twenty autonomous countries. He initiated a governmentstyle cabinet by assigning ministers of state like Bozorg-Mehr the philosopher and then revived the ancient notion of the 'Four Corners' of the world (four quarters of the federation) by creating four separate armies for the realm. He also created an advisory board of the nobles by dividing the political structure in the form of seven classes: the ministers, the priesthood, supreme judges, and four generals commanding the four armies (Masudi, 1977: 464-465). Khosro Anushirvan the Just (531579 AD) whose administration of justice is widely praised by early Islamic historian/geographers ${ }^{9}$ lent a more practical meaning to the Achaemenid concept of the 'four corner' of the realm by placing the twenty countries of the Iranian federation in four major Kusts or Pazgous. Each of these divisions was ruled by a viceroy or regent called Pazgousban or Padusban, and an espahbad or general commanded the army of each Pazgous. In his epic Shahnameh, Ferdosi describes these kusts or

\footnotetext{
${ }^{9}$ On Anushirvan's administration of justice see many early Arab and Islamic works of history and geography including: (A) Tabari, Mohammad Bin Jarir, Tarikh-e Tabari, Persian translation, 11 volumes, published by Bongah-e Tarjomeh va Nashr-e Ketab, Tehran 1974. (B) Maqdasi, al-Beshari, Ahsan at-Taqasim fi Marefat al-Aqalim, Liden 1906. (C) Biruni, Abu-Reihan, Qanoun-e Masudi, Published in Dakan 1955. (D) Ibn al-Faqih, Abu-Bakr Mohammad, Moktasar-e al-Boldan, 279 AH, Liden 1885. (E) Ibn Huqal, Mohammad, Surat al-Ardh, London 1938. (F) Estakhri, Ebrahim, Al-Masalek val-Mamalek, Liden 1889. (G) Hamavi, Abdullah Yaqut, Mo'jam al-Boldan, Cairo 1906. (H) Masudi, Abul-Hassan Ali Ibn Hussein, Moravvege az-Zahab, Pers. Trans., Bongah-e Tarjomeh va Nashr-e Ketab, Tehran 1977
} 
Pazgous in the following fashion: (1) Khorasan, including Qom and Isfahan; (2) Azarabadegan or Azerbaijan, including Armanestan (Armenia) and Ardebil; (3) Pars (Persia = southern Iran) and Ahvaz as well as territories of Khazar (most likely Khuzestan); (4) Iraq and Roman territories (Syria and Anatolia) (Ferdosi, 1985: IV, 415).

The development of the concept of territory in the Sassanid era went hand in hand with the evolution of the concept of boundary. It is of consequence to note that the term 'boundary' existed in middle Persian. The Persian equivalents for territory and boundary, attributed to the Sassanid period by Ferdosi, appear synonymously in the form of Marz-o Boum, literally meaning boundary and territory. But in Ferdosi's idiosyncratic manner of using these two terms, together they assume the meaning of 'political territory' or 'country' (homeland). Marz, meaning boundary, however existed on its own at the time, whereas another middle Persian term for boundary was also in use in the form of saman-mostly in reference to a line separating houses from one another in modern Persian. Both concepts of boundary and frontier were in practical use in the Sassanid era. While appointing governors or Padusbans for the vassal states, they appointed mayors or shahrigs for the cities. They created frontier zones in the west of their federation and boundary lines to its east.

In the west of their federation, the Sassanids appear to have developed two kinds of frontier-keeping states: the internal frontier states within their four Kusts: and the external frontier-keeping states, the most famous of which was the state of Hirah or Manazerah in Mesopotamia (Masudi, ibid).

On the north-western corner of the Persian Gulf, where Iranian and Roman empires' frontiers met, the vassal kingdom of Hirah was created in 5th century by the Sassanids on the river Tigris, not far from their Capital Ctesiphon. This frontier-keeping state, which was funded and protected by the Iranians, effectively formed a buffer state for Iran, thereby defusing pressures emanating from the Romans (Masudi, 1977: 240). In a similar move, the Romans created the vassal kingdom of Ghassan in the region now known as Syria (Masudi, 1977: 467). Moreover, it is notable that by virtue of its struggle against Arab rule,
Iran played the role of a cultural barrier throughout the Islamic era, which guaranteed its cultural survival in the subsequent periods. The precise location of the line of this cultural barrier can be defined somewhere around western peripheries of Iranian Plateau, in Mesopotamia, which played the same role in pre-Islamic era between the Persian and Roman empires. Here David Mitrani's theory of 'Middle Zone'-defined somewhere in Central Europe, around the river Danube (Mitrani, 1950) - can be applied to the status and implications of the geographical position of Iran in that region. This geography prevented total prevalence of other cultures over the Iranian Plateau throughout the history.

To their eastern flanks the Sassanids faced the Turans. Like the Romans, the Turans also engaged in numerous wars with the Iranians. But unlike their buffer zone arrangements with the Romans in the west, at least in one instance the Iranians created precise boundaries with the Turans in the east. This must have resulted from the degree in which rivalling powers to their east and west exerted pressure on their federation. While rivalries with the Romans in the West were of geopolitical nature which evolved in a situation similar to AngloRussian Great Game of 19th century in Central Asia, rivalries with the Turans to the east were of intense strategic nature culminating in many wars, which in turn necessitated demarcation of boundary lines that separated the two.

It is of consequence to note that not only did the Sassanids revive the Achaemenid organisation of the state and territory, but also fashioned the term Iranshahr (the country of Iran), which must have arguably been for the first time that a state or a nation had assumed an identity and/or a name independent of that of its ruling dynasties (Mojtahed-Zadeh, 1999 Iran va... 147-148). Having stated details of Bahram Gour's debate with the Roman emissary on the subject of varying Roman and Persian style of diplomacy and statesmanship, Ferdosi asserts that victorious in his campaign against eastern Turks, Bahram IV (Gour) (420438AD) commissioned construction of boundary pillars between Iran and its Turkish adversaries. He decided that river Oxus (Jeyhun) would form river boundary between the two sides. In his account of this development, Ferdosi says: 


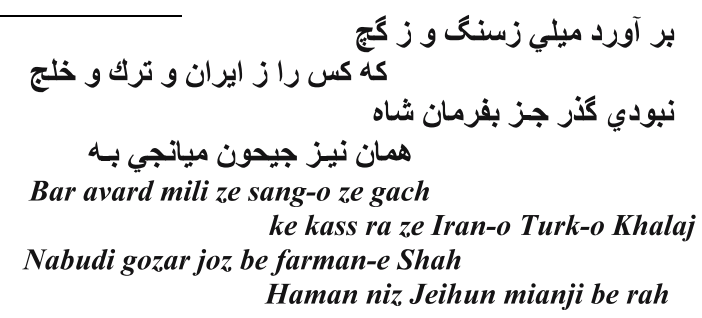

Literally meaning:

(he) constructed pillars of stone and chalk (plaster);

thereby ensuring that no one from Iran or Turk or other nationals

would pass beyond unless permitted by the Shah

who has also made Jeyhun (river Oxus) a median in the way

(Ferdosi, 1985: III, 394).

Thus is Ferdosi who asserted a thousand years ago that boundary pillars were erected six hundred years earlier, and that Iranians, Eastern Turks, and third party nationals were prohibited from going beyond them unless permitted by the king himself. The king had also defined River Oxus as part of the boundary (river boundary) between the two political entities. This may be seen as a clear example of the creation of a boundary line in ancient Iran corresponding to the modern understanding of the concept. Similarly, the permission from the king for passing beyond the boundary might be considered as an early form of a passport in today's term.

In the south, the Achaemenid federation included two satrapies: Aaval, the countries now known as Bahrain, Qatar and the Hasa \& Qatif provinces of Saudi Arabia, and the state (later became known as Masun) that included areas that in our time belong to Oman and the United Arab Emirates. The qanat underground irrigation system-invented in Achaemenid era-was introduced to the southern coasts of the Persian Gulf at the time of Darius I (Wilkinson, 1975: 98). There are indications that the Parthians (250 BC224 AD) made substantial progress in seafaring, but no evidence exists suggesting how the Achaemenids and/or the Parthians treated the issue of territoriality and boundary in those areas. The Sassanids by contrast, organised territories of southern Persian Gulf into two states or satrapies. In the western section, they created the kingdom of Hagar, embracing ancient Aaval, whereas in the eastern half they created the vassal kingdom of Masun or Mazun to embrace modern countries of Oman and United Arab Emirates (Hawley, 1970: 38). The indigenous population of all these areas was Iranian (Dravidians, Elamites etc.) before there were any Arabs living in the coastal south. Arab immigration to these areas began in the 2nd century AD. When the Kawadh (Qobads) ruled Masun in 6th century BC, immigrant Arabs succeeded in forming a large union. Faced with this massive tribal union of migrant Arabs the Iranian rulers treated the newcomers as Shahrvandan in Persian or Ahlalbilad in Arabic, literally meaning citizens, and accorded them a degree of autonomy under their own tribal leadership (Wilkinson, ibid.). Here the Iranian federative system is applicable even in the internal context of a vassal kingdom (see MojtahedZadeh, 1999).

\section{Conclusion}

There is no doubt that the Athenians initially developed the concept of 'democracy'. However, their practice of democracy was limited to no more than the limits of the varying social strata of a city. A nationwide application of democracy had to wait until Alexander the Great of Macedonia conquered Iran and adopted the Persian way of organizing the political space-i.e. as a quasifederal 'state' divided into discrete territories. The Achaemenids no doubt developed the original concept of state, but the idea of a vertically organized state with distinct and clearly demarcated 
boundaries matured under the Sassanids and began to influence Western civilizations.

When assessing the influence of Iran on the concepts of "state" and "boundary" in medieval Europe one might point to the biblical references to the Persian statehood and its tradition of respect for the rights of varying peoples (Isaiah, chapter xliv, Esther i, I, Ezra i, I etc.). According to these testimonies, despite spearheading military campaigns against the Greek cities and the Turans, the state organization created by the Achaemenid kings was essentially culturallybased and not grounded on rigid territorial conquest. This was particularly manifested in the Achaemenids' universal aspirations of statehood and good government. By developing their own version of a 'federative state' based on the notion of justice for all, the Iranians created a commonwealth of semi-independent nations or a federation of autonomous states, and arguably laid the foundation for the idea of 'state democracy' or 'democratic state'. This political structure of statehood was taking shape in Iran simultaneously with the advent of the Greek version of citizenship-centered democracy. In this regard it is important to note that Cyrus issued a charter in Babylonia (the text of which is now kept in British Museum) declaring equality and justice for individuals as well as freedom for religious-cultural entities in the realm. These notions formed the political fabric of the Persian State as Darius the Great also frequently refers to justice in the stales he bequeathed to posterity. This is to suggest that while the Athenians were concerned about the 'rights' of the individuals in society, the Persians were anxious to promote the rights of communities within their state system.

There are few other sources explaining the extent to which these ancient Persian traditions influenced the evolution of the Western concepts of "state", "boundary" and 'democracy', save for the works of scholars like Will Daurant (Pers. trans., 1988). Even a philosopher as widely misrepresented as Friedrich Nietzche whose writings many philosophers found difficult to take seriously, seems to have formed his view of the civilized Western man under the influence of ancient Persian philosophy of life (Thus Spoke Zarathustra, 1892). Ghirshman (Iran, 1962), for instance states that: under Alexander, 'monarchy by divine right' of the Iranians became an institution of Hellenism and later was taken up by Many European states (Nayer-Nouri, 1971: 152).

Levy, on the other hand, identifies Arab Caliphate as an intermediate culture through which the Persian tradition of statehood influenced modern world. Quoting early Arab and Islamic records he argues that: the Fakhri, an early-fourteenth century manual of politics and history, relates how the caliph, Umar, when at his wits end to know how to distribute the spoils of war which were pouring in, sought the advice of a Persian (Iranian) who had once been employed in a government office (of the Sassanid time). His suggestion was that a divan, a register or bureau, should be instituted for controlling income and this became the germ out of which grew the government machine that served the caliphate some hundreds of years. (Levy, 1953: 61). Of the influence of the Iranian legacy of "state" and statesmanship on the Arab Caliphate, an early Islamic historical account quotes Caliph Umar as saying: Verily have I learnt justice from Kesra (Khosro Anushirvan the Just) (Maqdasi, 1906: 18).

In his writings on the tradition of sacred kingship in Iran, Filippani-Ronconi, based on reliable Roman sources, states that: if we want to look into the successful diffusion in the Western world of certain institutions connected with kingship, in either the religious or the lay domain, we must go back to the Roman Empire, which was the first Western state to absorb a great deal of such outside influence, especially in its political and administrative institutions regarding the status of the Emperor. He then proceeds to cite examples of the influence of the Iranian tradition of statehood on the Western civilization by asserting:

'The heritage handed down by Iran to the West and still living in its ideological conceptions and cultural institutions is manifold. If its patterns are sometimes difficult to recognize and trace back to their origin, that is due to the fact that this legacy has been received through intermediate cultures and westernized models... The leading elements of what we could call the vertical organiza- 
tion' of the state are part of this age-old heritage. They were handed over to the modern world through the late Roman imperial structure and its medieval renaissance: through the institutions of chivalry and knighthood that, obscurely transmitted to European society in a Celtic-Germanic garb, were later Christianized ... (FilippaniRonconi, 1978: 67).

But just what happened to these concepts in the post-Islamic Iran might be of some interest to the scholars. The Arab Caliphate of Baghdad (Abbasid Caliphate 750-1258 AD) mimicked the Sassanid organization of territories almost in its entirety (Pourkamal, 1977: 7). They too created frontier-keeping states, one of which was Khozeimeh Amirdom of Qaenat that lasted until 1930s (see Mojtahed-Zadeh, 2004). But the prevailing notion of 'universality' in Islam would have left no scope for the evolution of the ancient idea of boundary formation in post-Islamic Iran. Consequently Iran's embrace of Shiite Islam in this period was essentially a desire to revive the country's cultural and national identity. The ancient Persian concept of 'justice' gained new currency by transmuting into one of the five basic principles of Shi'ite Islam. More importantly the expanding anti-Caliphate protestant Shi'ism in Iran merged with other local notions of identity, thus paving the way for the revival of the concepts of territoriality and statehood.

What the Safavids revived in terms of territorial organization of space was in reality a vague adaptation of Abbasid Caliphate's interpretation of the Sassanid system and not the original version. This vagueness of the new state structure suggests that Iran had departed from its own ancient traditions of state and boundary. This was no doubt a powerful handicap that manifested itself later, especially in the face of the conceptual and physical onslaught of modern European versions of nationality and statehood.

\section{Bibliography}

Arbery, A. J. (1953). The legacy of Persia. Oxford Clarendon Press.
Daurant, W. (1988). Tarikh-e tamaddon (History of Civilization) [Trans.]. Tehran: Enqelab-e Eslami (in Persian).

Ferdosi, H. A.-Q. (1985). Shahnameh (4th ed., Vol. III). Tehran: Javidan Publication [Original text, Javidan Publication 1364].

Filippani-Ronconi, P. (1978). The tradition of sacred kingship in Iran. In G. Lenczowski (Ed.), Iran under the Pahlavis. Stanford University, USA: Hoover Institution Press.

Ghirshman, R. (1962). Iran, Parthes et Sassanides. Paris: Gallimard.

Glassner, M. I., \& de Blij, H. J. (1989). Systematic Political Geography. New York: John Willy and Sons.

Hafeznia, M. R. (1997). In Daneshvar (Ed.), Power and cultural expansion in the subcontinent. (Vol. 17, pp. 17-25). Tehran.

Hawley, D. (1970). The trucial states. London: George Allen \& Unwin.

Iliff, J. H. (1953). Persia and the ancient world. In A. J. Arbery (Ed.), The legacy of Persian. Oxford: Clarendon.

Kristof, L. D. (1959). The nature of frontiers and boundaries (No. 49). Annals Association of American Geographers.

Levy, R. (1953). Persia and the Arabs. In A. J. Arbery (Ed.), The legacy of Persia. Oxford: Clarendon Press.

Lockhart, L. (1953). Persia as seen in the West. In A. J. Arbery (Ed.), The legacy of Persia. Oxford: Clarendon Press.

Maqdasi al-Maruf be-al-Beshari (1906). Ahsan at-Taqasim fi Marefat al-Aqalim (written in $375 \mathrm{AH}$ ) (2nd ed.) Liden.

Masudi, Abul-Hassan Ali Ibn Hussein (Arab geographer/ historian of 4th century AH, Moravvege az-Zahab (Propagator of the Way), Persian translation 1977 by Abul-Qassem Payandeh, Bongah-e Tarjomeh va Nashr-e Ketab, Tehran.

Mitrani, D. (1950). Evolution of the middle zone. Annals of American Political and Social Science, September.

Mojtahed-Zadeh, P. (1974). New studies on the royal road [translation from Victor W. Von Hagen's article in The Geographical Magazine of June 1974, as appeared in monthly Daneshmand (Scientist) of Tehran, Vol. 11, No. 11 (Series No. 131), September].

Mojtahed-Zadeh, P. (1999). Iran va Irani boudan (Iran and to be Iranian), Ettelaat Syasi-Eqtesadi (Political-Economic Ettelaat) quarterly of Tehran, Vol. XIV, Nos. 3\&4 (147-148) and 5\&6 (149-150), Tehran Azar \& Day and Bahman \& Esfand 1378 (winter of 1999).

Mojtahed-Zadeh, P. (1999). Security and territoriality in the Persian Gulf. London: Curzon Press (c. 3).

Mojtahed-Zadeh, P. (2004). Small players of the great game. London and New York: Routledge/Curzon (c. II \& III).

Murphy, A. B. (2003). Dominant territorial ideologies in the modern state system: Implications for unity within and beyond the islamic world, Paper presented to the 2nd international congress of the geographers of the islamic world, Tehran, 16 \& 17 September. 
Nayer-Nouri, A. H. (1971). Iran's contribution to the world civilization. Vol. II., Tehran.

Nietzsche, F. (1883-1885). Thus spoke Zarathustra. Formally published in 1892 .

Pourkamal, M. (1977). Administration divisions of Iran. Plan and Budget Organization: Tehran.

Tavakoli, A. [1372] (1993). Empratouri, Shahanshah (Empire, Shahanshahi), Ayandeh Monthly, Vol. IXX, (7-9).
Taylor, P. J. (1989). Political geography (2nd ed.). London: Longman Scientific \& Technical.

Templeton, P. L. (1979). The Persian prince. London: Persian Prince Publication.

Vadiei, K. (1974). Moghadamehi bar Joghrafiay-e Ensaniy-e Iran. (An introduction to the human geography of Iran). Tehran: University Press.

Wilkinson, J. (1975). The Julanda of Oman. The Journal of Oman, Vol. I, London. 